The Historical Journal

http://journals.cambridge.org/HIS

Additional services for The Historical Journal:

Email alerts: Click here

JOURNAL

Subscriptions: Click here

Commercial reprints: Click here

Terms of use : Click here

\title{
VIA RASELLA, 1944: MEMORY, TRUTH, AND HISTORY
}

JOHN FOOT

The Historical Journal / Volume 43 / Issue 04 / December 2000, pp 1173 - 1181

DOI: null, Published online: 06 March 2001

Link to this article: http://journals.cambridge.org/abstract_S0018246X00001400

How to cite this article:

JOHN FOOT (2000). VIA RASELLA, 1944: MEMORY, TRUTH, AND HISTORY. The Historical Journal, 43, pp 1173-1181

Request Permissions : $\underline{\text { Click here }}$ 
The Historical fournal, 43, 4 (2000), pp. I I 73-I I 8 I Printed in the United Kingdom

(C) 2000 Cambridge University Press

\section{REVIEW ARTIGLE}

\section{VIA RASELLA, 1944 : MEMORY, TRUTH, AND HISTORY}

L'ordine è già stato eseguito: Roma, le Fosse Ardeatine, la memoria. By Alessandro Portelli. Rome: Donzelli, r 999. Pp. vii +448. ISBN 88-7989-457-9. L.50.0oo.

The battle of Valle Giulia: oral history and the art of dialogue. By A. Portelli. Wisconsin: Wisconsin: University Press, I997. Pp. xx+354. ISBN o-299-I5374-6. \$2 I.95. [Inc.'The massacre at Civitella Val di Chiana (Tuscany, June 29, I944): Myth and politics, mourning and common sense', in The Battle of Valle Giulia, by A. Portelli, pp. 140-6o.]

Operazione Via Rasella: verità e menzogna: i protagonisti raccontano. By Rosario Bentivegna (in collaboration with Cesare De Simone). Rome: Riuniti, I996. Pp. I47. ISBN 88-3594 I 7 I - 7. L.6.900.

La memoria divisa. By Giovanni Contini. Milan: Rizzoli, I997. Pp. 275. ISBN 88- 733027-2. L.30.00o.

Anatomia di un massacro: controversia sopra una strage tedesca. By Paolo Pezzino. Bologna: Il Mulino, i 997. Pp. 243. ISBN 88-i 5-06054-5. L.26.ooo.

Processo Priebke: Le testimonianze, il memoriale. Edited by Cinzia Dal Maso. Rome: Il Mondo, 3 edn., i 996. Pp. 220. ISBN 88-8 I 75-0 I0-4. L. I8.ooo.

Morte a Roma: il massacro delle Fosse Ardeatine. Nuova edizione aggiornata. By Robert Katz. Rome: Riuniti, i 996. Pp. xxiv+257. ISBN 88-359-4057-5. L.6.50o.

Dossier Priebke. By Robert Katz. Milan: Rizzoli, i996. Pp. i 76. ISBN 88- I 7-84503-5. L.24.000.

Le radici e le ali: partigiani a Roma (and video). By Fabio Grimaldi et al. Rome: Manifestolibri, i 996. Pp. I60. ISBN 88-7285-098-3. L.29.900.

Via Rasella: leggenda e realtà della resistenza a Roma. By Aurelio Lepre. Bari: Laterza, I 996. Pp. 87. ISBN 88-420-5026-i. L.9.000.

Via Rasella, cinquant'anni di menzogne. By Pierangelo Maurizio. Rome: Maurizio edizioni, i 996. Pp. I 23. L.20.00o.

Storia e memoria di un massacro ordinario. Edited by Leonardo Paggi. Rome: Manifestolibri, г 996. Pр. г65. ISBN 88-7285-103-3. L. I4.00o.

Il linciaggio di Carretta: Roma I944: violenza politica e ordinaria violenza. By Gabriele Ranzato. Milan: Il Saggiatore, I 997. Pp. 254. ISBN 88-428-04 I 8-5. L.25.0oo.

I grandi processi. 2. Herbert Kappler. Edited by Wladimiro Settimelli. Rome: L'Unità, I994. Pp. г9 I. Supplement with L’Unità.

'Identity history is not enough'. By Eric Hobsbawm in idem, On history. London: Weidenfeld and Nicolson, i997, pp. 266-77. ISBN o-297-8igi5-I. £20. 
The facts: what happened? On 23 March I 944, a column of $5_{5} 6$ police troops from the Bolzen regiment attached to the German army were marching through the centre of occupied Rome. Between I 5.45 and I $5.5^{\circ}$ a bomb exploded in the narrow street of Via Rasella killing thirty military policemen (three more were to die later) as well as at least two Italian civilians. The bomb had been placed by an official armed Gap partisan unit which had been active in Rome for some months. The German troops responded by firing indiscriminately into the houses on the street and rounding up the residents of Via Rasella. The next day, 335 people were taken to the Fosse Ardeatine Caves just outside the city and shot over a period of four and a half hours. ${ }^{1}$ The victims had been taken from various official and unofficial prisons, Via Rasella, and other areas. Only three had already been condemned to death (for partisan activity), I 54 were under investigation by the Germany military police, and seventy-five were in custody purely because they were Jewish. Other victims were taken from Regina Coeli (Rome's prison) or selected from those picked up around Via Rasella. The next day (25 March) a German army poster appeared across Rome and in newspapers. It accused 'criminal elements' of planting the bomb and added that 'The German Command... has ordered that for every German killed ten communist-Badoglian criminals will be shot. This order has already been carried out.'2

\section{I}

The dispute over the facts. Ever since the bomb exploded in Via Rasella, these facts themselves have been in dispute. In various arenas of public opinion - the press, the courts, the streets, political parties, and historical journals - these facts have been worked over, debated, and restated. Constant accusations of conspiracies, mendacity, and cover-ups have dominated these disputes. There is no need here to enter into this debate in detail, as other historians have already spent time in the accurate reconstruction of what actually happened in March 1944 in Rome. ${ }^{3}$ What remains of great interest are the dynamic historical and political debates surrounding these facts and these controversial events. These debates are not confined to Rome or to Via Rasella and the Ardeatine Caves, but take in big questions of participation, the resistance,

\footnotetext{
1 The best account of the massacre remains that of Robert Katz, Death in Rome (London, 1967), Morte a Roma (Rome, I996).

${ }^{2} \mathrm{My}$ translation. For the original see Alessandro Portelli, L'ordine è già stato eseguito: Roma, le Fosse Ardeatine, la memoria (Rome, I999, p. 3). Badoglio was the elderly general appointed by the king as prime minister after a palace coup overthrew Mussolini in July I943. Italy effectively changed sides in the war after 8 September 1943.

${ }^{3}$ For example, there are debates over the nationality of the soldiers 'Germans or Italians?'; the role of Togliatti; the age of the victims; the 'Open City' character of Rome; the disputes within the partisan movement; the time of the bomb, etc., etc. Most of these issues are easily cleared up, and see both Portelli, L'ordine, and Rosario Bentivegna (the partisan who actually lit the fuse on the bomb), Operazione Via Rasella (Rome, I996), for precise details, but some other questions (civilian deaths, the role of the Vatican) are still unclear. This dispute over the basic events themselves is also present in other cases of 'divided memory' between partisans and victims, see Giovanni Contini, La memoria divisa (Milan, I997), and Paolo Pezzino, Anatomia di un massacro (Bologna, r 997).
} 
consensus, memory, and responsibility. In this review I will concentrate on the broad lines of some of these debates and the questions opened up by the rich historiography which has begun to emerge from Italy in the r 990 os.

\section{I I}

The historical and political debates. The historical debate over Via Rasella and the massacre and the bomb needs to be seen within the context of a continuing discussion which began almost immediately after Liberation. Since r945 two competing myths have dominated debate over the resistance, and until the late i 980 s the political overtones of the dispute dominated the need for real historical inquiry and openness. In short, the 'need' to support the resistance myth born out of the anti-fascist tradition overrode the desire to look more carefully (on the left) into the real support for and impact of the resistance. In this version of events, the resistance was a mass movement which stretched from Abruzzo upwards and those who opposed (or took no part in) the armed struggle were mainly dismissed as fascists or collaborators. ${ }^{4}$ The alternative myth, given historical weight by Renzo De Felice in the I970s, was of a resistance supported only by a tiny, ideologically committed minority. The vast majority took no part in the movement and this huge 'grey zone' (made up of many of those who had given their 'consensus' to Mussolini) stood quietly by, waiting for the war to end. As Aurelio Lepre has written 'the dominant sentiment was... the hope of saving one's own skin' ${ }^{5}$ If we translate these myths to Via Rasella, we get two classic (and very different) versions of events. In the first, Via Rasella was a heroic act of war carried out, yes, by a necessarily small group but with the (active and passive) support of vast sectors of the urban population. This is the image of resistance Rome, of Porta San Paolo (the site of the first acts of armed resistance in Italy) of the 'red' Rome depicted by Portelli in the zones of San Lorenzo or the Castelli Romani.

For the other myth, Via Rasella was a pointless and vanguardist terrorist attack which achieved nothing and cost the lives of 335 innocent victims in the Ardeatine Caves. Most Romans were opposed to this type of action, convinced of Rome's special 'open city' status ('the Pope is here', as one character states in Fellini's Roma, 'they won't bomb Rome') and the imminent departure of the Germans. Various other (recent) versions go further, depicting Via Rasella as a conspiracy (against dissident partisan groups, for example). Within this version lie the various propagandist details which have survived for so long - the chance the partisans had to give themselves up and save those massacred, the age and nationality of the troops killed by the bomb, the death of by-standers, especially a young boy called Pietro Zuccheretti, the principal emotional weapon (complete with photo) in the anti-partisan campaign of the ${ }^{1990{ }^{6}}{ }^{6}$

4 'The partisans were well aware that they could count on the greater part of the population of Rome, if necessary, for help during an escape, for hiding places and changes of identity' (my translation), Bentivegna, Operazione Via Rasella, p. 22.

5 Via Rasella (Bari, I996), p. I3. And again, with more specific reference to Rome, 'the great majority of Romans... were employed... only in the struggle to survive until the moment of liberation', ibid., p. I 7 .

${ }^{6}$ The confusing question of civilian deaths at Via Rasella (Lepre attributes twelve years to Zuccheretti, Portelli eleven, and Bentivegna thirteen) has never been fully clarified, and the absence of civilian victims from Rosario Bentivegna's personal account, Achtung Banditen! Roma I944 (Milan, I983) did not help matters. Two civilian victims were mentioned in the I 948 Kappler 
The historical proponents of this thesis range from the vulgar conspiracy theories of right-wing journalists to the sophisticated historical polemic of Lepre (based partly on the somewhat flimsy premise of a small collection of interesting but not representative telephone conversations recorded after the bomb in Rome). ${ }^{7}$

Neither of these versions captures the complexity and trauma of the resistance, nor of the specific circumstances surrounding Via Rasella. Many Romans were terrified (and angered) by the attacks on German troops, but many supported the resistance (in myriad ways) and helped the opposition organizations. As with all the German massacres during the war, the blame and the responsibility have been laid, obviously, at the door of the German army itself. But Via Rasella shows that many people (including the Italian fascists, but also large sectors of the ordinary population) blamed the partisans for causing trouble and inviting revenge attacks. The specific features of Via Rasella should not prevent these debates being placed within the series of studies of divided memory which began to appear in Italy in the I990s. A particularly important moment for this approach was represented by Claudio Pavone's path-breaking Una guerra civile (Turin, I99I). The international conference In memory held at Arezzo in I994 was another key moment and produced two important books, Giovanni Contini's La memoria divisa, Leonardo Paggi's Storia e memoria di un massacro ordinario as well as providing the inspiration for Paolo Pezzino's fascinating research on another German massacre near Pisa, Anatomia di un massacro. ${ }^{8}$

\section{I $\mathrm{V}$}

Memory and responsibility. The idea of divided memory derives from the 'surprising' discovery in the I 990 of of alternative memories held by the families of victims of various local massacres perpetuated by German troops in 1944 throughout the Arezzo region in Tuscany. ${ }^{9}$ Many people who had lost relatives and friends in the massacres not only

sentence, but the famous photo which appears to be of Zuccheretti was not 'discovered' until the I 990s. Zuccheretti's brother was persuaded to take legal action against Bentivegna, the man who actually lit the Via Rasella fuse, in r 997. For the final sentence see 'Attentato di Via Rasella in Roma del 23 Marzo i 944 - definizione come legittima azione di guerra, ai sensi del D. L. VO LGT. i 2 Aprile r 945 N. I94' Cassazione - Sezione I Penale sent. n. I56o/99 - Presidente R. Teresi Relatore A. Mabellini), available on the internet.

${ }^{7}$ Lepre adds that the way in which the resistance myth of the massacre has evolved tends to play down any Italian responsibility for the horrors of the war.

8 The organizer of the Arezzo conference, Leonardo Paggi, had witnessed the Civitella massacre as a three-year-old when his father was amongst those killed. See the papers collected in L. Paggi, Storia e memoria di un massacro ordinario (Rome, I 996) and, more recently, two fascinating collections edited by Paggi, La memoria del nazismo dell'Europa di oggi (Florence, I997), and Le memorie della repubblica (Florence, I999). For other comments on this conference see Eric Hobsbawn, On history (London, I 997), pp. 266-77, and above all Alessandro Portelli's article 'The massacre at Civitella Val di Chiana (Tuscany, June 29, I944): myth and politics, mourning and common sense', now in his The Battle of Valle Giulia (Wisconsin, I997), pp. I40-6o.

9 Portelli rightly points out that this 'discovery' is less surprising for any historian who has looked at the non-left press in the post-war period, where the hostility to the partisans is often palpable and intense. I found the same trend for the so-called 'capital of the resistance' - Milan - whilst researching my article on the history of San Vittore prison in the I $943^{-6}$ period, see 'The tale of San Vittore: prisons, politics, crime and fascism in Milan, I943-1946', Modern Italy, 3 ( 1998$)$, pp. $25^{-48 .}$ 
blamed the partisans for the massacre, but had carried forward this hostility to the actions of the resistance for fifty years. Put very simply - and these narratives are neither simple nor linear nor lacking in internal contradictions - for these survivors and their families (and others) the principal blame for the massacres, whilst obviously perpetrated by the German troops, lay with the partisans. The latter had carried out irresponsible and useless attacks which had left the civilian population defenceless and open to German ferocity. These narratives not only fly in the face of traditional left-national discourses concerning the resistance, but also tend to create problems for much of the historiography of the partisan movement published during the Cold War, as well as the numerous myths from the Fratelli Cervi down. ${ }^{10}$

The divided memory of Via Rasella is more complicated than the situation at Civitella Valdichiana in Tuscany which forms the basis for the work of Contini and Paggi and was also part of the inspiration for Portelli's book on Via Rasella and the Fosse Ardeatine. At Civitella, in June I944, a tiny partisan operation (leading to the deaths of three German soldiers) was followed, eleven days later, by the horrific massacre of most of the male population of the village (I I 5 people). Since then, the families of the victims have carried forward a version of events which holds the partisans themselves responsible for the massacre and has seen clashes between these partisans and these families over the fifty years since the massacre. Contini's excellent study (mainly but not only based on oral history interviews) reconstructs the events leading up to the massacre (which was probably not a reprisal at all) and examines in detail the competing memories which have divided Civitella ever since. His explanation lies in a combination of historical and geographical factors and socio-psychological (and gender) features linked to the isolation of Civitella and the particular way in which the mourning and narrative processes relating to the massacre were created and perpetuated over time (leading, for example, to court cases, clashes at public ceremonies, and even violence). It should be underlined, however, that the 'holders' of this antipartisan memory are limited almost exclusively to the victims' families. Contini plays down the extraordinary fact that the partisan leader who ordered the attack on the Germans at Civitella was later elected mayor of the area. The 'anti-partisan' nature of the town's memory did not seem to stretch beyond a select group closely linked to the massacre itself. ${ }^{11}$ This detail gives more credence to psychological explanations of this alternative memory linked to the specific nature of pain, scapegoating, and mourning after such massacres.

For the Fosse Ardeatine, the story is a different one. Many of those related to the victims did blame the partisans, and some (five people in all) even took specific partisans to court (where they lost). The I 998-9 judicial proceedings regarding the Via Rasella partisans was inspired by the brother of the small boy killed accidentally by the bomb in I944. However, many others blamed the Germans, or the Italian authorities, or Mussolini. In September i 944, a number of widows of Fosse Ardeatine victims took part

10 The seven Fratelli Cervi (Cervi brothers), shot by the Nazis in I943, were perhaps the most important Communist martyrs of the Resistance. Their house became a museum and a research foundation. Their story became a film and a best-selling book. Their father (Papa Cervi) was frequently asked to speak at Communist Party rallies and anti-fascist meetings. See Alcide Cervi, I miei sette figli (Rome, I955).

11 The reader longs for more details or some information on this mayor's activities in an area apparently so hostile to him. Similarly, an ex-partisan was also elected mayor of the Pisan town studied by Pezzino. 
in a spontaneous attack on Donato Carretta, ex-director of Regina Coeli, during the trial of Pietro Caruso, ex-police chief of Rome. Carretta, only at the trial as a witness, was horribly beaten to death by the crowd and hung by his feet outside Rome's prison. This act (and anger) was hardly that of a group which blamed the resistance (or specific sectors of the resistance) for the massacre. ${ }^{12}$ Only a minority of the victims' families took refuge in anti-partisan memories similar to those found at Civitella. Other aspects of the massacre go far beyond the personal and the specific, such as the large Jewish presence, part of Italy's own holocaust. For the Ardeatine massacre, the debate over the partisan action has often taken on a far more political (and judicial) character than in 'forgotten' local vicenda such as that at Civitella. What is clear from all these new studies is that the issue of divided memory is a historically specific one, and must be studied with an open mind without creating blocks of memory on one side or the other. As Portelli points out in his own contribution to the Civitella debate, individual memories themselves are often in contradiction and there are 'a multiplicity of fragmented and internally divided memories'. ${ }^{13}$ None the less, these memories represent a crucial (and until now absent) contribution to the debates and history of the resistance and the post-war period. ${ }^{14}$ It is also significant that these studies all take the subjectivity of these events as of great historical importance beyond the actual facts of each case. ${ }^{15}$ As Portelli has written, and these studies show, 'these stories and memories are themselves historical facts'. ${ }^{16}$

\section{V}

Portelli's study. Alessandro Portelli's extremely rich and beautifully organized study of Via Rasella and the Fosse Ardeatine massacre is based above all on a series of wideranging oral testimonies. Portelli states in the first chapter that his main task is to explain the diffusion of the myths concerning the partisans and Via Rasella which have had such a strong effect in Rome since the war. Above all, he concentrates on the claim that the partisans should have given themselves up to the Germans to prevent the massacre. This claim is manifestly perverse. As we have seen, the announcement of the massacre was published on 25 March with the phrase (which is also the title of Portelli's book) 'this order has already been carried out'. None the less, the idea that the partisans could have saved the victims of the Ardeatine massacre has found widespread support in Rome and elsewhere. Portelli is able to unpack this myth through the use of

12 See Gabriele Ranzato, Il linciaggio di Carretta (Milan, I997), for a fascinating account of this event, and a thought-provoking discussion of political and collective violence. Some of this event was captured on film (by Luchino Visconti) and later released as part of the documentary Giorni di gloria ( I945). 13 'The massacre at Civitella Val di Chiana', p. I42.

14 Pezzino has researched a smaller massacre in a Pisan town (Guardistallo) in I 944 (forty-six people were killed after a clash between retreating German troops and partisans which left eleven of the latter dead; the Americans liberated the village the very next day). He found very similar instances of deep-rooted hostility to the partisans and their activities. Pezzino's analysis is too refined to go into detail in this broad survey, but his account confronts a series of questions regarding memory, the Civitella case, and the identity of the resistance which deserve consideration in future debates. One difference in this case (from that at Civitella) is that the anti-partisan attitudes appear to have faded somewhat in recent years, whilst at Civitella they seem to be as strong as ever.

15 These 'new' histories have all tended to use 'new' methodologies, above all a microhistorical approach, oral history interviews, and anthropological and psychological explanatory tools.

16 L'ordine, p. I8. 
interviews with a whole range of protagonists-partisans, families of the victims, politicians of all hues, historians, and journalists. ${ }^{17}$

But this book is not just about Via Rasella or the Fosse Ardeatine massacre. Portelli is also concerned with the memory of popular, anti-fascist, and working-class Rome, with middle-class Rome, with the individual narratives which help us to understand a historical event of this importance, with the judicial aspects of the case and with the big theoretical issues of memory, forgetting, consensus, and struggle. ${ }^{18}$ Portelli begins each chapter with some names of the victims - the whole list is read out at the annual ceremony - and weaves the individual stories of those who 'ended up at the Ardeatine caves' into his broader narrative. As he writes, the victims and their personal histories 'sum up the whole complex stratification of histories of a big city'. ${ }^{19}$ Whilst all of those killed were men, the memory of the massacre has been carried forward above all by women - widows, mothers, sisters - and their voices (at times the oral history is overused) and those which move the story forward from place to place, victim to victim, moment to moment, trial to trial (this is also true for the Civitella and Pisan cases). Portelli places Via Rasella and the Ardeatine massacres back in their historical context (the history of this period is not self-contained, and neither begins with the bomb nor ends with the massacre). The partisans had been active for months before the Via Rasella bomb attack (without reprisals from the Germans) and the resistance continued after the massacre. The experience of the whole war pervades the book - from the start of the resistance after 8 September to the Allied bombings to the mass deportations of Jews and others. The book is particularly strong on the places linked to these moments - the huge popular housing projects of the Roman periphery, the caves and the later monuments and plaques, the red traditions of San Lorenzo and the Castelli Romani, the communist brick-workers of Valle Aurelia with their cult of the anarchist leader Errico Malatesta.

17 Of course, the question of whether the partisans should have handed themselves into the Germans is not just one of possibility, but also moral responsibility. On countless occasions, the protagonists of this story (and of the resistance) have reiterated their belief that they would not have handed themselves in anyway (although Bentivegna has occasionally claimed otherwise). In a war, they argue, you do not hand yourself over to the enemy without a fight. Of course, the legal and political debates over the bomb have often concentrated on the military legality and legitimacy of the Gap group and the Via Rasella bomb, and their claim to represent the Italian state and the Italian army at that point in the war. With some changes of emphasis (from the 'illegitimate act of war' of the I 948 sentence to the 'legitimate act of war' of i 950 and the latest I 999 sentence of the high court) the legal decisions have all been in favour of the partisans, and the award of medals to Bentivegna and Carla Capponi (a fellow partisan from the group who planted the bomb) by the Italian state underlines this legitimacy. Of course, all these questions are complicated by the unprecedented military situation in I $943-4$ after 8 September, with former allies becoming the enemy, the dissolution of the regular army and the so-called 'death of the nation'. For all these questions see Portelli, L'ordine.

18 In fact, there are times when Portelli uses material which bears little relevance to the Via Rasella case and, although this is almost always interesting and readable, it takes the analysis away from the main events under discussion. This is true of some of the social history of Rome in the first part and also of the more contemporary interviews, such as those which touch on a recent murder case at the University of Rome, in the latter part of the volume. To use a cinematic term, some of this material should have ended up on the cutting-room floor. ${ }^{19}$ Portelli, L'ordine, p. I 2. 


\section{I}

Priebke. The whole Via Rasella-Fosse Ardeatine controversy may well have faded into the same foggy memory as many other massacres if it were not for the extraordinary events surrounding the discovery, arrest, trial, and conviction of former SS Captain Erich Priebke for his role in the Fosse Ardeatine massacre, fifty years on. ${ }^{20}$ Priebke's role in the massacre was important, but not pivotal (in Katz's original account he only gets five, relatively minor, citations in the index). Priebke was ordered to prepare the list of victims and personally took part in the massacre, as did many officers and ordinary soldiers. None the less, as events unfolded in the r 990 os, Priebke's activities in 1944 and (above all) his trial became central to the debates we have set out above. The presence of Priebke became the key to the satisfaction of the thirst for justice felt by many families of the victims and the Jewish community after the escape of Kappler (The high-ranking German officer who actually organized the massacre) from his Italian hospital bed in I977. The lack of any kind of real repentance by Priebke himself probably added to the exaggeration of his role, as did the surreal news of his two visits to Rome as a tourist in the post-war period, where he travelled under his own name.

Priebke's trial was held in front of the semi-defunct military tribunal of Rome and, right from the beginning, the judges responsible for the case revealed themselves as totally inept and under-prepared to preside over a case of this importance. The judges were surprised by the big public attendance at the hearings and the massive coverage in the Italian (and foreign) press. The trial was dominated by technical, military-legal issues which left those looking for 'justice' confused and angry. For example, much time was spent in discussions over Priebke's responsibility in the death of the so-called 'extra five' victims who died in Ardeatine Caves. This debate tended to legitimate the whole idea of vendetta massacres in war and reduce the case to a technical one centred on the personal 'errors' (not moral errors) of Priebke as list-holder.

In themselves, the Priebke trial and re-trial did not add more than a few details to the whole story of the Fosse Ardeatine. But the trials themselves became part of that experience, especially the debates in the press. The right-wing Il Giornale under Vittorio Feltri, Il Tempo, and Indro Montanelli-a distinguished Italian journalist - all ran fairly consistent campaigns either against the partisan role in the whole sequence of events or, as in Montanelli's case, in direct support of Priebke as a 'fellow soldier'. ${ }^{21}$ The role of the families and Jewish community during the hearings was constant and revealed how deeply the massacres had affected the fabric of certain parts of Rome and its peoples. The most explosive moment came with the first verdict of the court in July i 996. On hearing that Priebke was guilty but 'not punishable due to his good behaviour since the

20 Priebke, eighty-three in I 996, was discovered by a US TV crew in Argentina in I994 and specific political circumstances in Argentina led to his extradition to Italy fairly rapidly. Many of the principal protagonists of both Via Rasella and the massacre were still alive in the late I99os, Bentivegna, Capponi, and others from the Gap group who planted the bomb, Priebke, and the mysterious ex-Nazi and post-war spy Karl Hass (who also took part in the massacres).

21 Pierangelo Maurizio's volume, Via Rasella, cinquant'anni di menzogne (Rome, I996), is a good representation of this campaign, popularized by the fascist journalist Giorgio Pisanõ in his Sangue chiama sangue (Milan, I994) (I8th edition!). For Maurizio, the Communist conspiracy extends everywhere; the Germans were merely willing dupes in a fiendish Italian Communist Party plot to eliminate rivals in the resistance by forcing them into a reprisal. Much of this is hyperbolic and without substance, but Maurizio did manage to locate some new information about the civilian victims which had been kept fairly quiet until the rg9os. 
massacre ${ }^{22}$ and the fact that he was 'following orders' (sic) a large crowd blocked the exit to the courtroom for hours. Justice minister Flick was forced to re-arrest Priebke on a technicality and a re-trial changed the original decision. Priebke remains in custody in Italy to this day (summer 2000).

\section{I I}

Conclusion: unanswered questions and future research. The Cold War (and the continued threat of fascism in the post-war period) had a damaging effect on the understanding of the resistance in Italy. Historians either ignored or failed to discover the mosaic of narratives and explanations which characterized actual, lived, subjective experiences of occupation, war, struggle, and loss. The heroic, unitary vision of the resistance simply ignored other versions which were not necessarily pro-fascist or even anti-partisan in an ideological sense. The fine work of Contini, Paggi, Pezzino, and Portelli allows us (in different ways) to try and understand not just the conflict between occupiers, oppressors, and partisans, but also between different visions of the usefulness and support for isolated acts of guerilla warfare against a retreating army. Only in this way, the heroism of those who did choose to fight can be restored to its proper historical (and nonmythical) context. As the German army burnt and massacred its way through Italy in I944, thousands were killed in horrific fashion. ${ }^{23}$ The continuing debates over responsibility and memory can never be resolved, but these new accounts (most of which come from the left) help us to understand the myriad responses to those events across the peninsula and through time.

UNIVERSITY GOLLEGE LONDON

JOHN FOOT

\footnotetext{
${ }^{22}$ Priebke's personal defence document gives some examples of this 'good behaviour': 'En l'Argentina sono socio vitalizio dell'Automobil club e membro honorario dell'Asociazione cultura Germania-Argentina de Bariloche', 'Since 1933 I have come to love Italy and her people', 'My wife's best friend was a Jewish woman', Cinzia Dal Maso ed., Processo Priebke (Rome, 1996), pp. 2I $7-18$.

${ }^{23}$ See also the Taviani brothers' marvellous film La notte di San Lorenzo, I982, based around a massacre at San Miniato in Tuscany. But see also Phil Cooke's discussion of the events depicted in this film in his review of recent work on the resistance due to appear in a forthcoming special issue of the journal Modern Italy, 52 (2000).
} 